\title{
The Effect of Education Based on Theory of Planned Behavior in Mothers About Behavior Prevention from Development Retardation in Children Aged One Year in Qom
}

Azam Sadat Tabatabai Seresht MSc. Student, Department of Health Education and Health Promotion, Faculty of Medical Sciences and Technology, science and research branch, Islamic Azad University, Tehran, Iran

Reza Tavakoli

* Associate professor in Department of Health Education and Health Promotion, Faculty of Medical Sciences and Technology, science and research branch, Islamic Azad University, Tehran, Iran. (Corresponding Author): r-tavakoli@srbiau.ac.ir

Mahmod Mahmodi

Professor, Department of Health, Faculty of Medical Sciences and Technology, science and research branch, Islamic Azad University, Tehran, Iran

Received: 27 October 2018

Accepted: 31 December 2018

DOI: 10.30699/ijhehp.7.3.263

\begin{abstract}
Background and Objective: Developmental and behavioral disorders are among common problems in pediatric medicine. Early diagnosis of these disorders is important so there can be intervention and treatment. The aim of this study is to evaluate the impact of education based on the theory of planned behavior on promoting preventive behaviors of child's development disorder on mothers in Qom in 2018.
\end{abstract}

Materials and Methods:In this study which was conducted as a quasi-experimental intervention in 2018, a sample of 106 mothers with children aged one year were randomly assigned to two groups of control and test in 2018. The data collecting tool was the questionnaires based on theory of planned behavior that was completed twice: before and 1 month after the education. Educational intervention was performed in 4 sessions for the test group. Finally, the data were collected and analyzed using paired t-test, independent t-test, and Chi square in the context of the SPSS 22.

Results: Before the intervention, the two groups had no significant difference in terms of demographic variables and mean scores of different structures of theory of planned behavior. However, after the intervention, there were significant differences between test and control group in terms of mean score and standard deviation, the educational effect, knowledge score $(2 / 85 \pm 2 / 37)$, attitude $(7 / 13 \pm 3 / 28)$, subjective norm $(6 / 64 \pm 3 / 66)$, perceived behavioral control $(11 / 05 \pm 4 / 33)$, behavioral intention $(9 / 8 \pm 3 / 92)$, and behavior $(16 / 94 \pm 8 / 10)(P<0.001)$.

Conclusion: The findings of this study showed the effect and efficiency of the theory of planned behavior on promoting preventive behaviors of child's development disorder in mothers.

Keywords: Theory of planned behavior, Educational intervention, Child's development disorder, Mothers

Paper Type: Research Article.

Citation (Vancouver): Tabatabai Seresht A, Tavakoli R, Mahmodi M. The Effect of Education Based on Theory of Planned Behavior in Mothers About Behavior Prevention from Development Retardation in Children Aged One Year in Qom. Iran J Health Educ Health Promot. Autumn 2019;7(3): 263-273. [Persian]

C Citation (APA): Tabatabai Seresht A., Tavakoli R., Mahmodi M. (Autumn 2019). The Effect of Education Based on Theory of Planned Behavior in Mothers About Behavior Prevention from Development Retardation in Children Aged One Year in Qom. Iranian Journal of Health Education \& Health Promotion., 7(3),263-273. [Persian] 


\section{آموزش مبتنى بر تئورى رفتار برناملريزىشده بر ارتقاى رفتارهاى بيشَيرىكننده

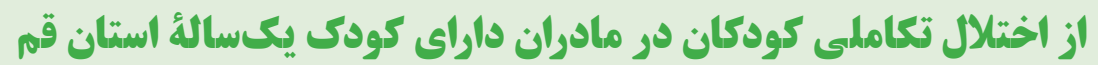

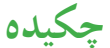

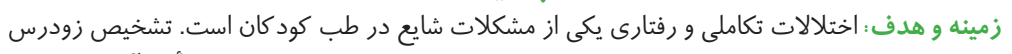

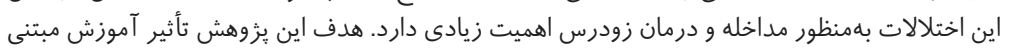

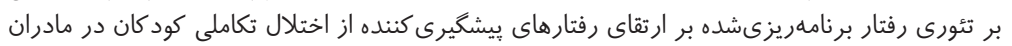

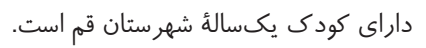

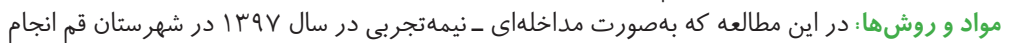

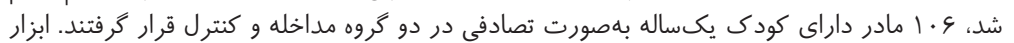

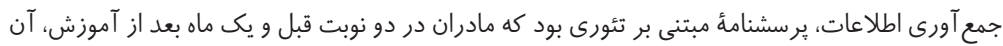

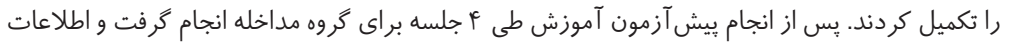

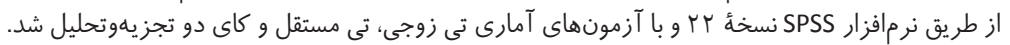

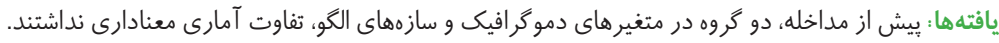

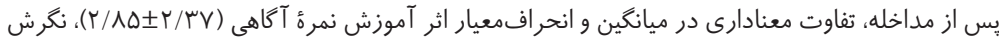
(Y)

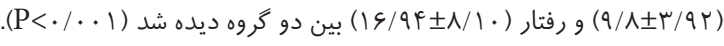

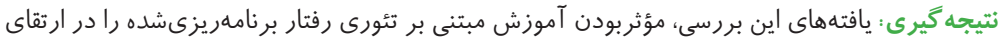

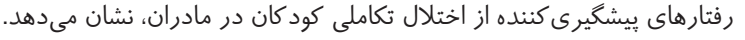

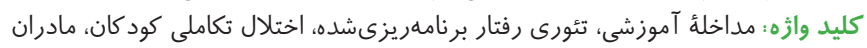

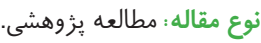

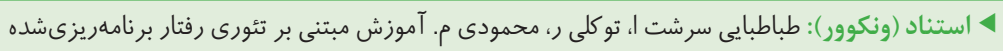

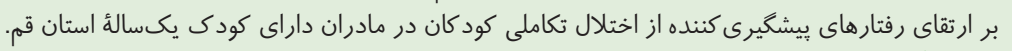

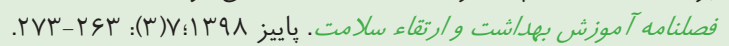

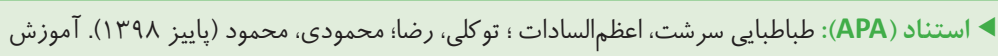

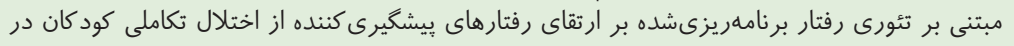

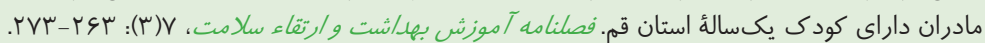

اعظم السادات طباطبايى سرشت

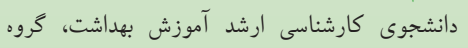

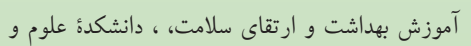

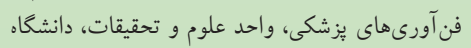

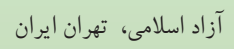
رضا تو كلى

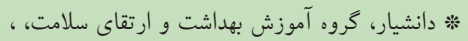

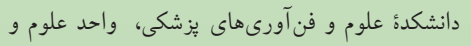

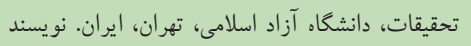

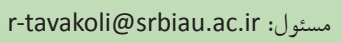

$$
\text { محمو د محمو دى المي }
$$

استاد ، گروه مدير يت خدمات بهداشتى، دانشكدة علوم و فن آورىهاى بز شكى، واحد علوم و تحقيقات، ، دانشكاه آزاد اسلامى، تهران، ايران

تاريخ دريافت: ه تاريخ يذيرش: ه 


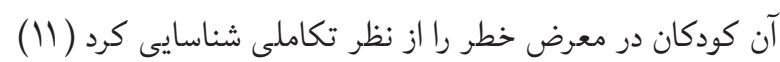

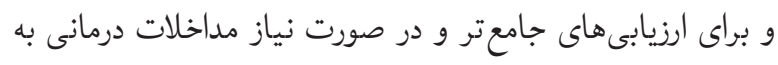

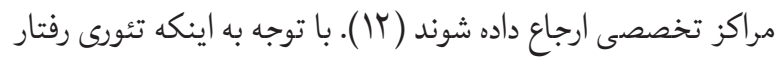

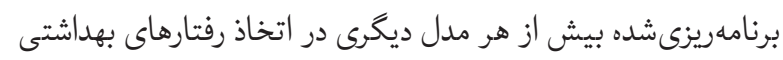

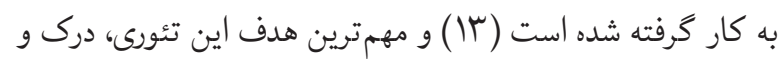
يميشبينى تأثيرات انكيزشى بر رفتار فرد است و از طرفى مهمترين

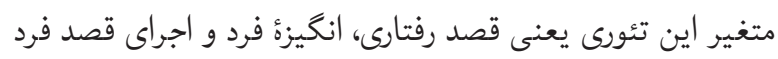
كه معادل برنامهريزى براى عمل است را تحت تأثير قرار مى دهد،

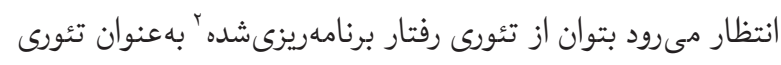
مناسب در برنامههاى بهداشتى استفاده كرد (سا). استفاده از اين

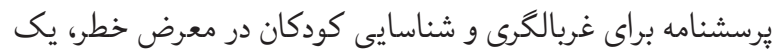

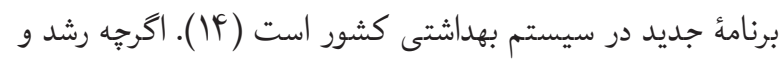

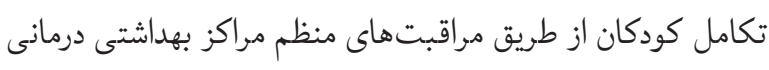

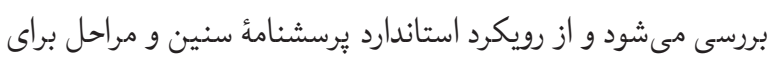

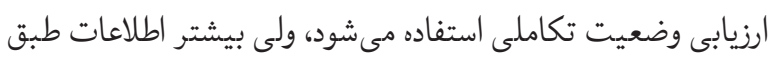

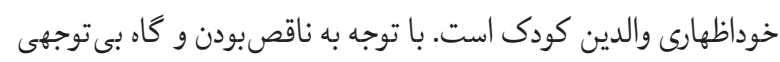

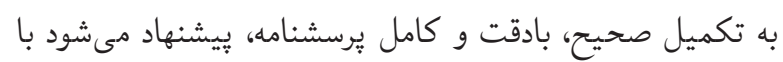

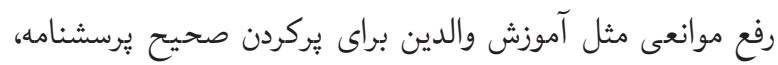

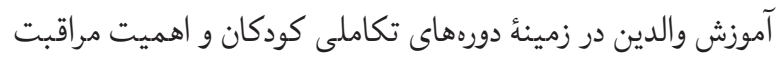
كودكان، شرايط خوب و سالمترى براى رشد و تكامل آنان فراهم شود (10). با وجود تكامل طبيعى در اكثر كودكان، تعدادى از كودكان داراى اختلال تكاملى حداقل در يك حيطه بودند (If)؛ بنابراين

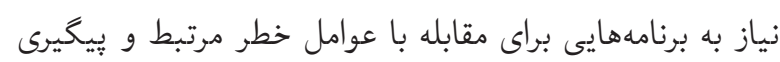

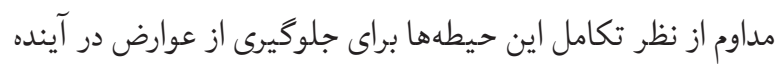

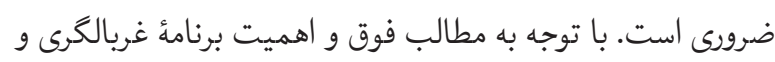

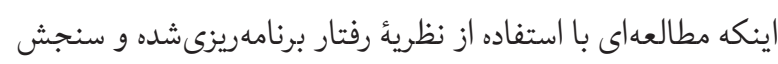
قصد رفتارى مادران در زمينه بيشخيرى از اختلال تكامل كودكان بنان

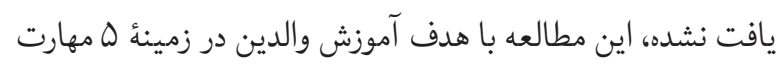
تكاملى كودكان و انجام رفتارهايى براى كودكان كه موجب تكامل

2. Theory of Planned Behavior
جامعه براى رسيدن به توسعه، نيازمند افرادى سالم و توانا است. در

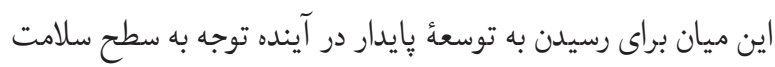

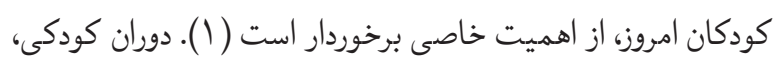

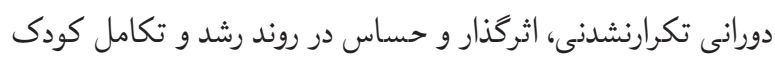
است و هركونه نقص در اين دوران خسارت جبران نايذيرى براى

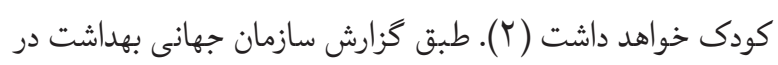

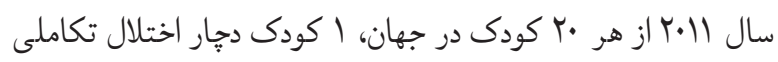

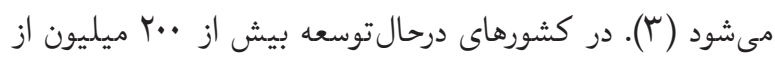
كودكان زير ينج سال، به رشد كامل نمى رسند (Y) أ). لذا براى داشتن

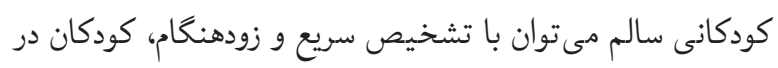

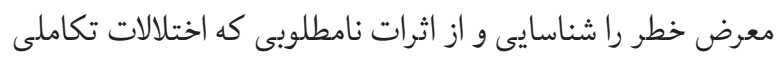

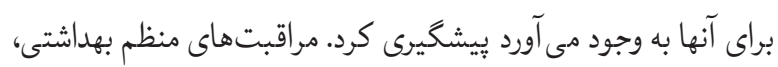
فرصتى براى شناسايى اختلالات تكاملى در جهت رفع آنها است (Y). اختلال در تكامل كودكان با وزن موقع تولد ارتباط دارد و ورات

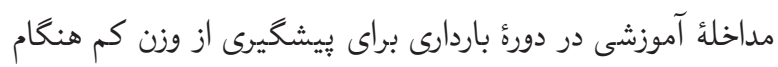

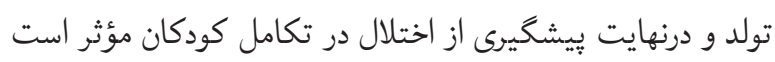
(ه). اختلالات تكاملى شامل حيطههاى مختلف (حركات عمده،

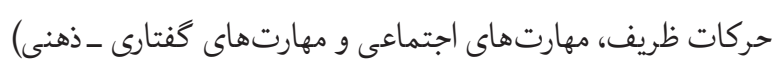
مىشود كه تأثير عظيمى بر عملكرد فردى و اجتماعى كودى دارد

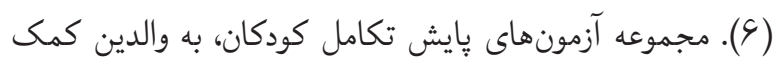

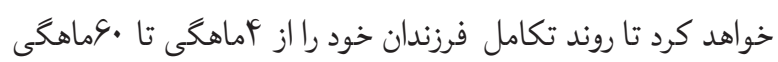
در ينج حيطة تكاملى (ارتباطات، حركت درشت، حركت ريز، حل مسئله، شخصى ـ اجتماعى)كه به صورت ترسشنامه به والدين داده

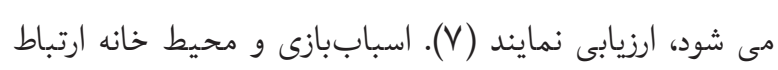

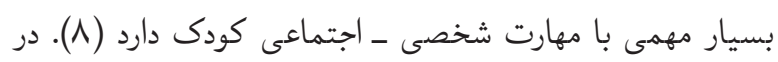

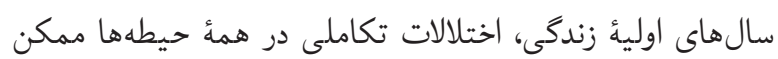
است رخ دهد؛ بنابراين تشخيص زودرس و مداخلهُ بههنگام براى زئل

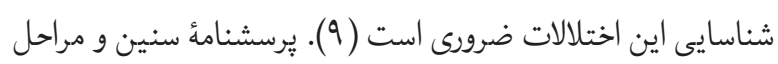
يك استاندارد تخصصى براى ارزيابى تكامل و مهارتها ' (ASQ)

1. Ages and Stages Questionnaires 
و با استفاده از بِرسش نامهُ سنين و مر احل (ASQ) كه استاندارسازى

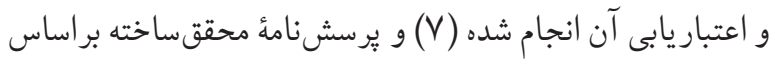

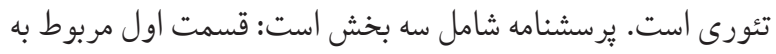

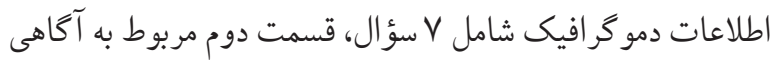

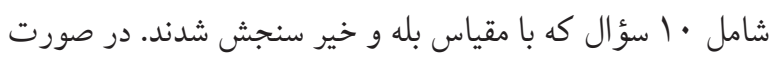

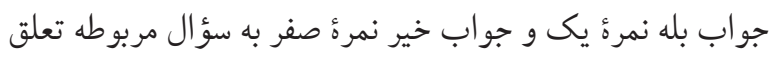
كرفت و قسمت سوم براساس ساز ههاى تئورى رفتار برنامهر يزى شده

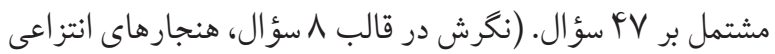
در قالب \ سؤال، كنترل رفتارى دركشده در قالب الاسؤال،

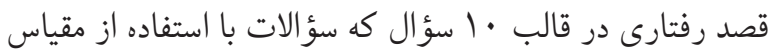
F F • درجهاى ليكرت سنجش شدند. در صورت كاملا موافق نمرءٔ

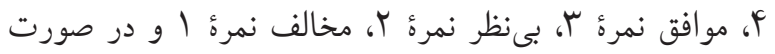

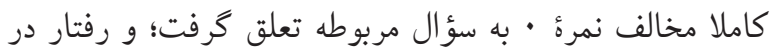

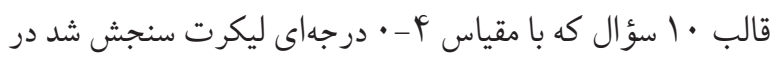

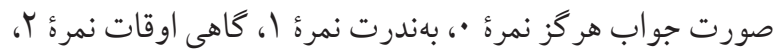

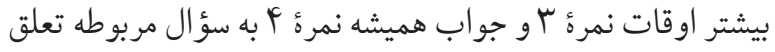

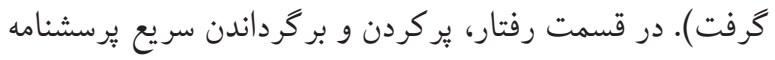

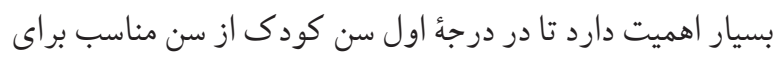
پاسخ دادن به سؤ الات يرسشنامه نكذرد و در مرتبهُ دوم در صورت وجود كوجكترين اشكال در تكامل او اقدام بهموقع انجام شود. پاسخ به سؤ الات يُرسشنامه را به يك بازى خانو ادگى تبديل كردند

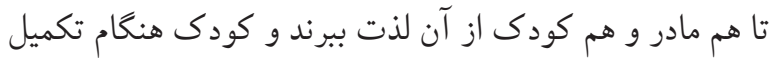

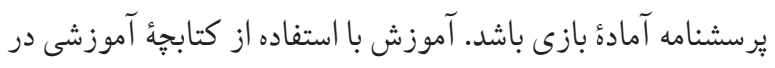

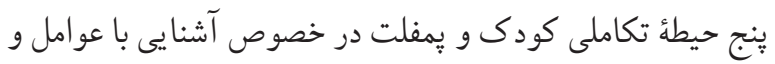
عوارض اختلال تكاملى در كودكان از سوى يُوهشكر در جلسات

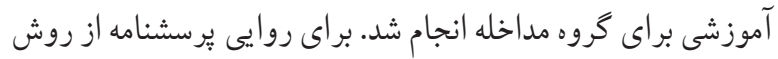

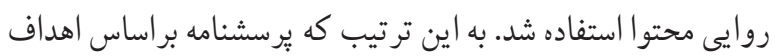

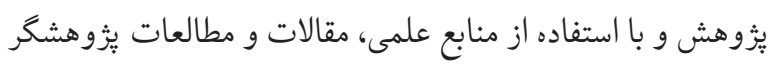

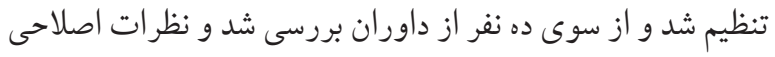

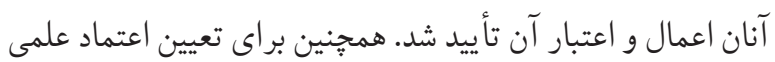

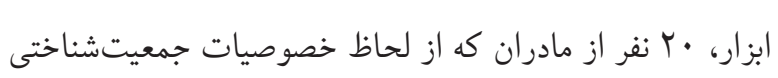

بيشتر كودكان مىشود، به تكميل صحيح، بادقت و كامل برسشنامه

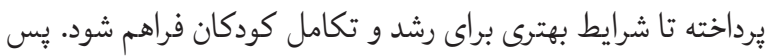
ييشگيرى از اختلال تكاملى كودكان براى مادران كود لوك يكساله ضرورى به نظر مىرسد. روش كار مطالعهُ حاضر مطالعهاى مداخلهاى از نوع نيمه تجربى قبل و بعد، همراه

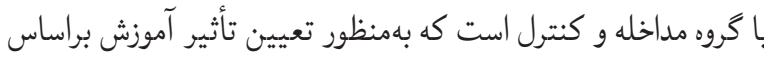

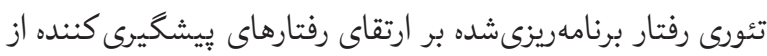

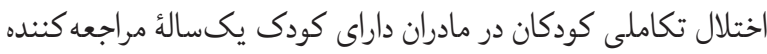
به مراكز جامع سلامت استان قم در سال لوسا طراحى و اجرا شد. معيارهاى انتخاب نمونه و ورود به تحقيق شامل اين موراد بود: مادر سرا داراى كودى يكساله باشد، تكميل برسشنامئ ASQ در تمامى وري

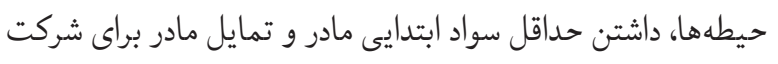
در همة جلسات آموزشى. معيارهاى خروج از مطالعه عبارت بودند از: كودكان نارس؛ مراجعهُ مادر در خارج از سن يكسالكى كودك؛ همكارى نكردن مادر. براى نمونه كيرى ابتدا شهر قم به دو منطقه تقسيم شد (بهعنوان طبقات) و از بين •ا مركز جامع سلامت موجود در بهري هر منطقه (بهعنوان خوشهها) يك مركز بهصورت تصادفى، بهعنوان مداخله و يك مركز بهعنوان كنترل (درمجموع دو مركز) انتخاب شد. حجم نمونه با استفاده از فرمول تعيين حجم نمونه و با درنظركرفتن

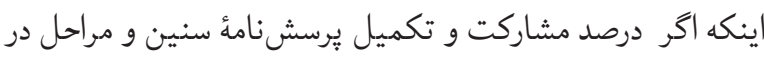

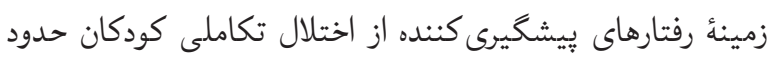

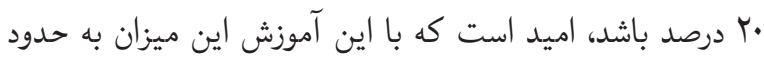

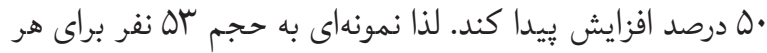

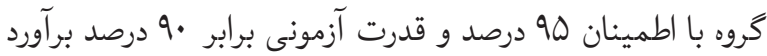

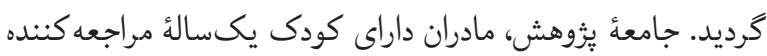
به مراكز جامع سلامت و محيط بُزوهش مراكز جامع سلامت استان قم هستند. فرمول محاسبة حجم نمونه به شكل زير است: $\mathrm{n}=2\left(\mathrm{z}_{1-\alpha / 2}+\mathrm{z}_{1-\beta}\right)^{2} \mathrm{P}(1-\mathrm{P}) /\left(\mathrm{P}_{1}-\mathrm{P}_{2}\right)^{2}$ ابزار خرد آورى دادهها در اين مطالعه از طريق خود خزارشدهى 
مر احل انجام شد. جلسة دوم بهمنظور تغيير در نكرش مادران بركزار

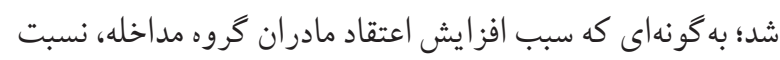

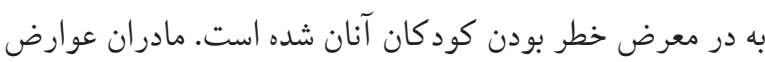
مختلف جسمى، روانى، اجتماعى و اقتصادى ناشى از اختلال در

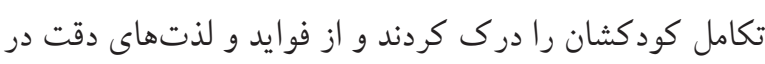

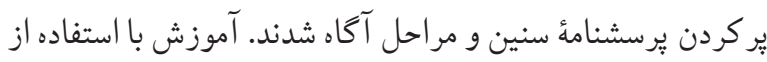
روش سخنرانى، بحث گروهيى و مشاورة فردى براى كروه مداخله

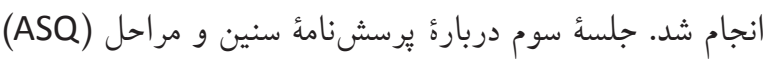

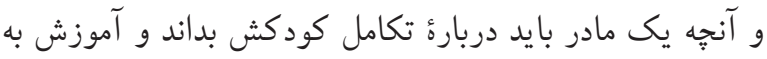

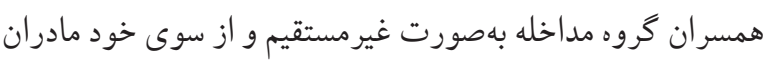

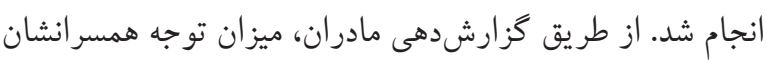

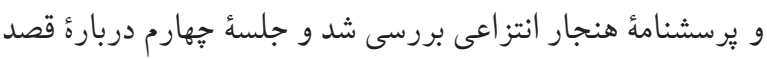

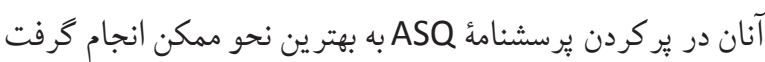

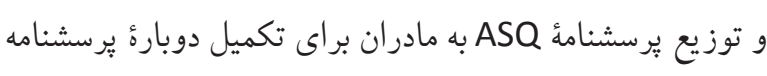

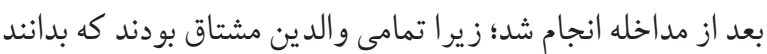
آيا فرزندشان بهطور طبيعى تكامل مى يابد. تشخيص غلط دربارة

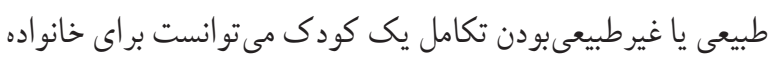

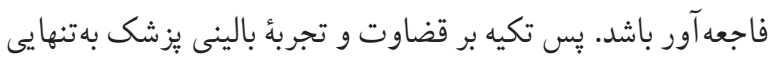

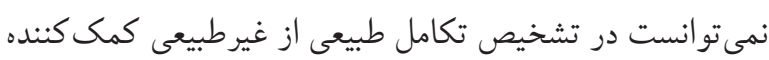

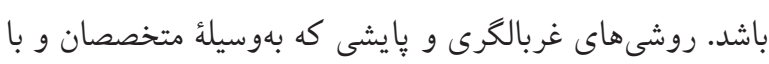
حداقل دخالت والدين انجام مى شود، والدين را در كير نمى سازد.

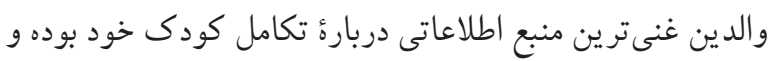

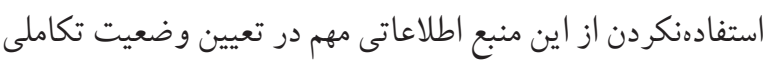
كودك منجر به ناقص بودن ارزيابى مىشود. يك ماه بعد از مداخله

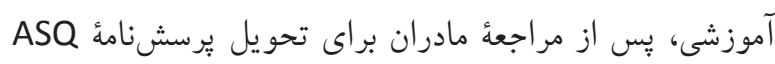

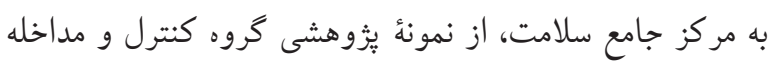

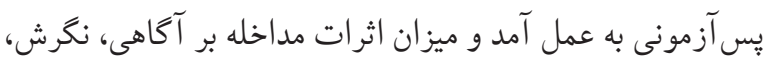
هنجار انتزاعى، كنترل رفتارى در كشده، قصد رفتارى و رفتار در

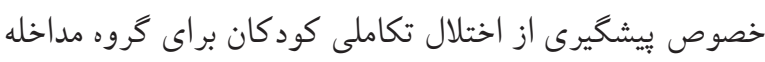

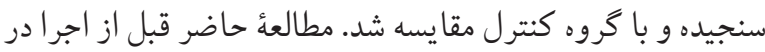

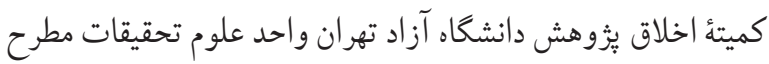

مشابه جمعيت هدف شناسايى شده بودند، يرسشنامه را تكميل

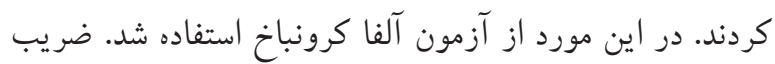

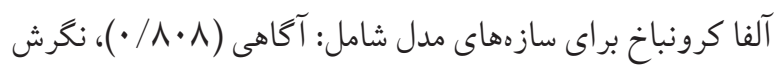

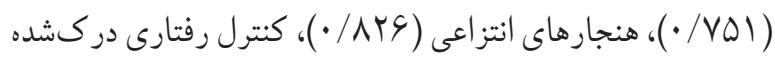

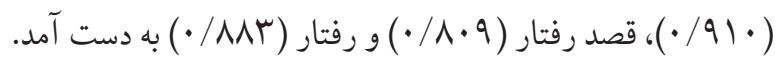

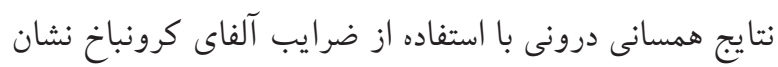

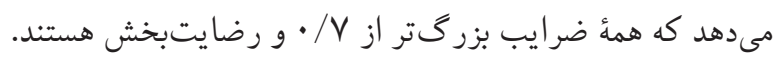
با واردشدن در سامانهُ سيب، بين بروندة تمام كود كانى كه از تيرماه

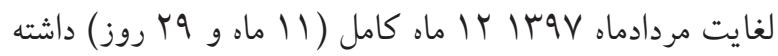

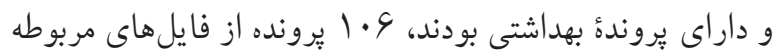

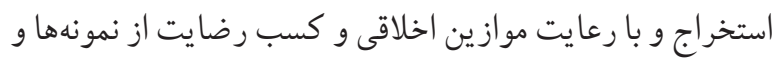
بيان محرمانهماندن اطلاعات، براى كردآورى اطلاعات قبل از مدان مداخله

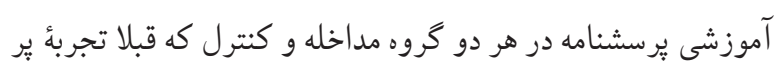

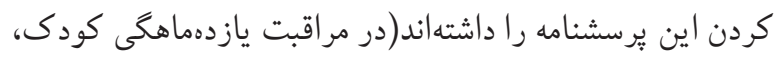

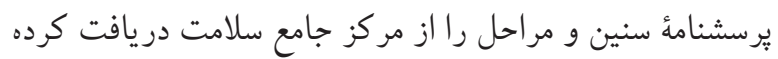

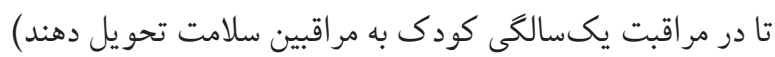

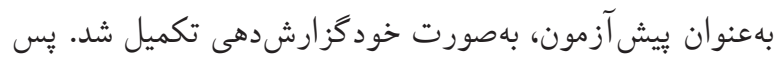

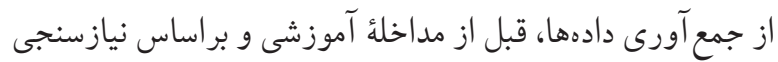

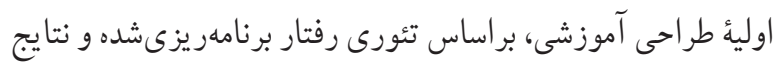

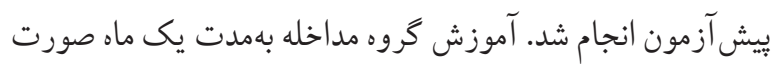

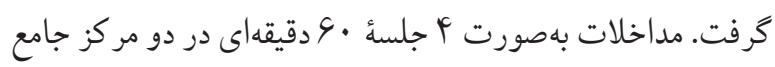

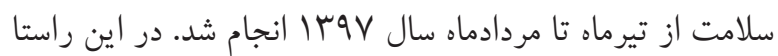

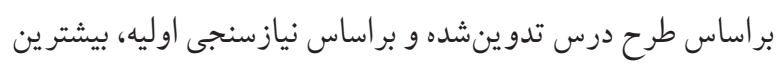

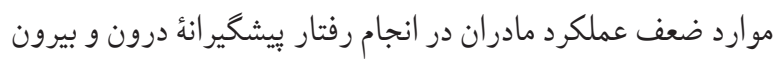

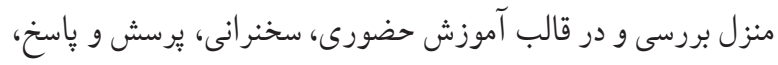

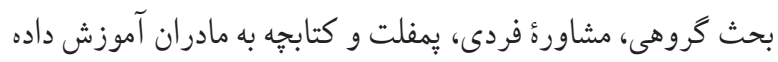

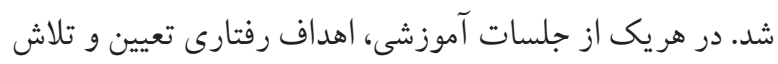
براى رسيدن به اين اهداف با استفاده از روشهاى مختلف اندان إنام

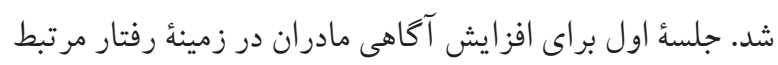

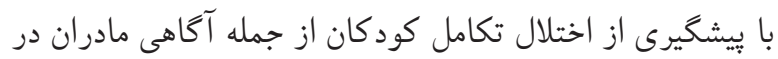

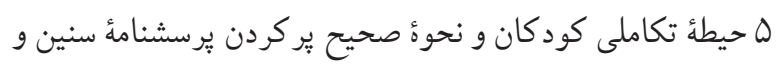


زايمان طبيعى است كه Y نفر بوده و OY/A درصد افراد نمونه

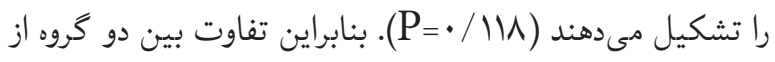

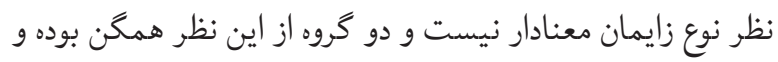

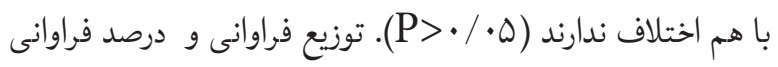
نمونه يُزوهش برحسب تحصيلات مادر در كروه مداخله نشان مى دهد

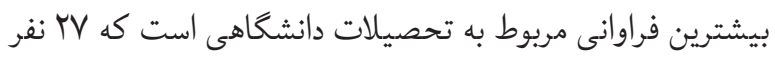
هستند و 9 • • ه درصد افراد نمونه را تشكيل مى دهند. در كروه كنترل بيشترين فراوانى مربوط به تحصيلات دانشخاهى است كه ب ب نفر

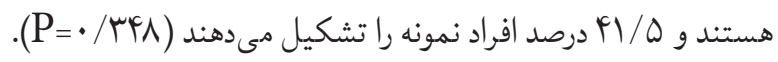

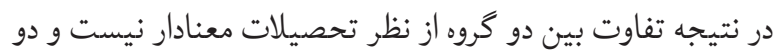

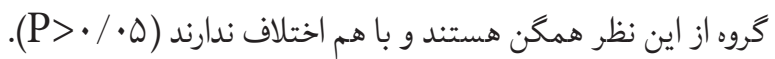
توزيع فراوانى و درصد فراوانى نمونهُ يُزوهش برحسب تحصيلات

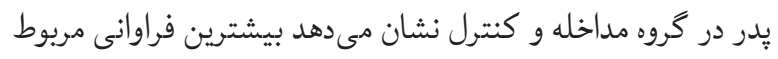

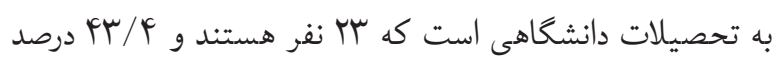

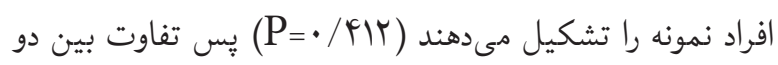

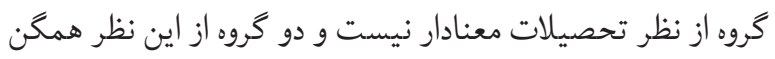

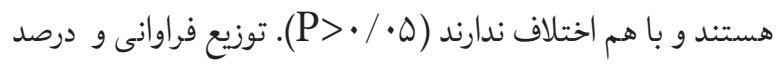

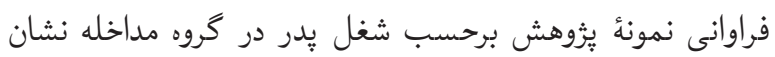

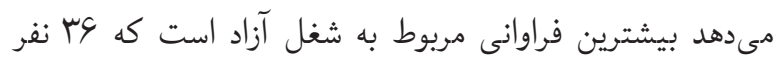

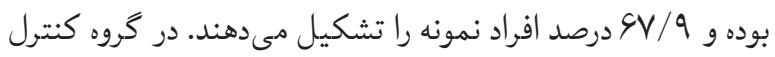

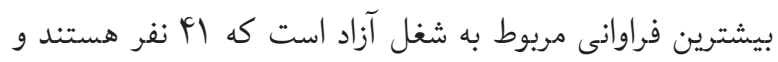
V درصد افراد نمونه را تشكيل مىدهند (PV/F تفاوت بين دو گروه از نظر شغل معنادار نيست و دو كروه از اين

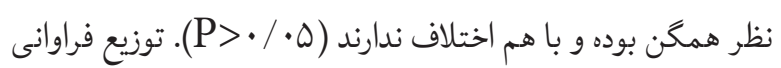
و درصد فراوانى نمونهُ يُوهش برحسب شغل مادر در گروه مداخله

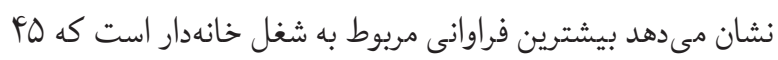

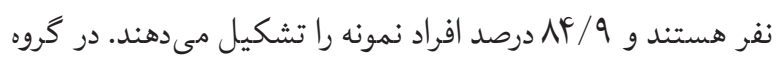

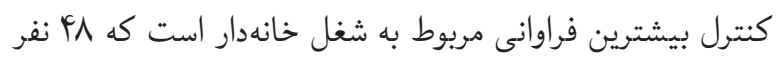

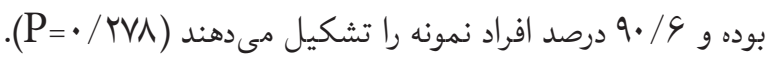
در نتيجه تفاوت بين دو گروه از نظر شغل معنادار نيست و دو دود

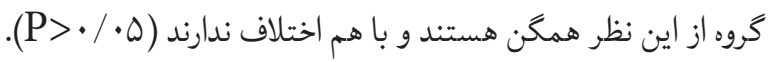

و با كد اخلاق IR.IAU.TMU.REC.1397.086 به تصويب رسيد. همجنين قبل از انجام مداخله نيز ضمن بيان اهداف مطالعه، رضايت شفاهى از نمونهها اخذ و شركت در مطالعه بهصورت داوطلبانه انجام

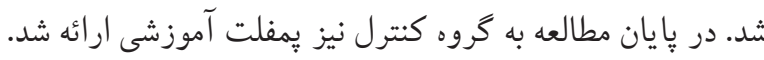
درنهايت دادههاى دو گروه، مرحلةُ قبل و يك ماه بعد از مداخلة

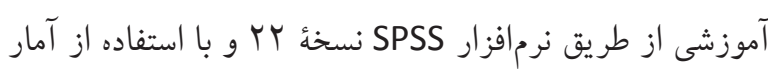

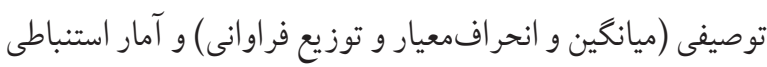
(كاى دو، تى زوج و تى مستقل) مورد تجزيهو تحليل قرار كرفتند.

يافته ها

در اين بُّوهش 9.1 مادر داراى كودى يكساله در دو كروه مداخلة rه نفر و كنترل ساه نفر بررسى شدند. اطلاعات توصيفى برخى از

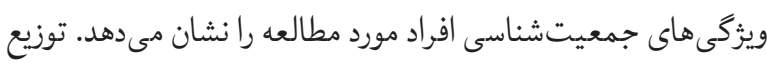

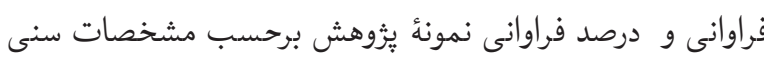

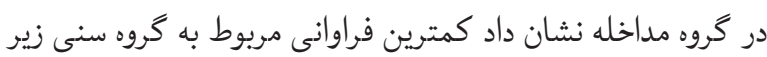

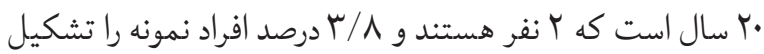

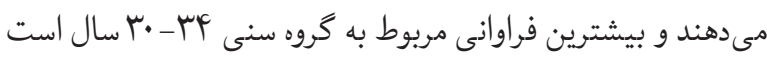

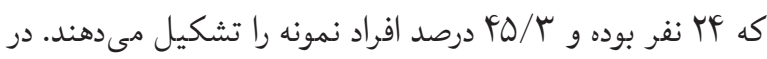

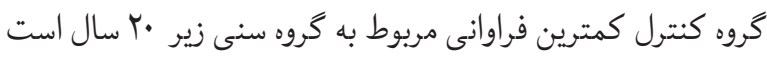

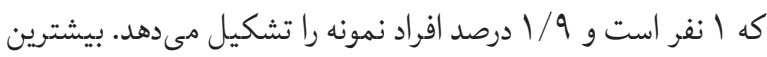

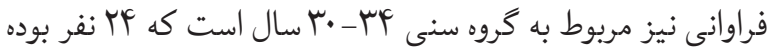

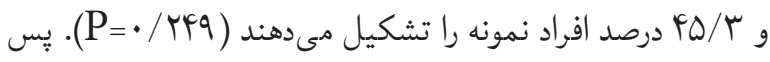

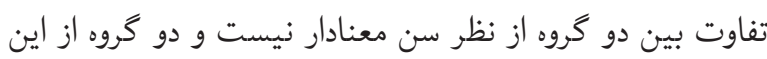

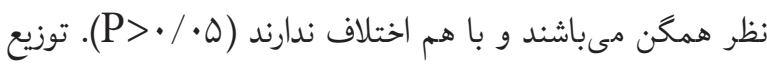
فراوانى و درصد فراوانى نمونهُ يُوهش برحسب نوع زايمان نشان

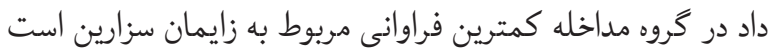

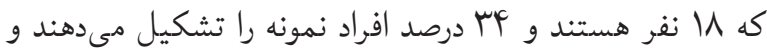

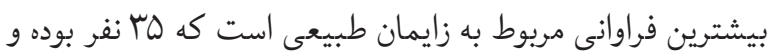

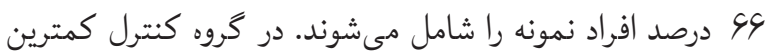

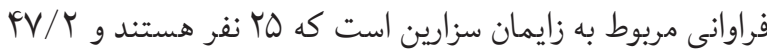

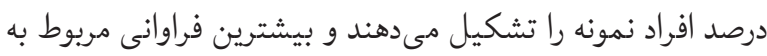


جزئيات مشخصات جمعيتشناختى به تفكيك هر گروه در جدول آمارى معنادارى مشاهده نشد. براى مقايسٔ دو اثر آموزش كروه

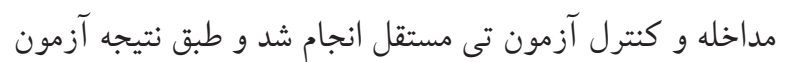
آورده شده است.

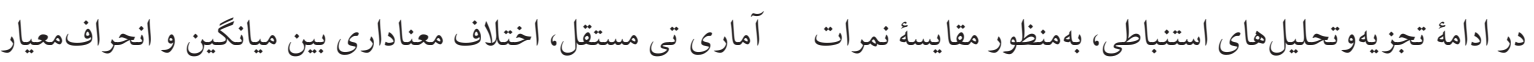

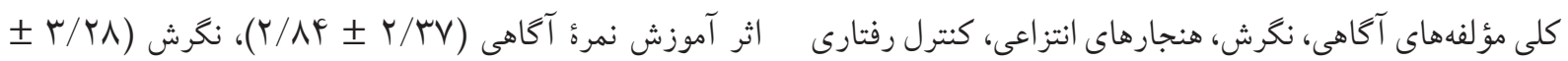

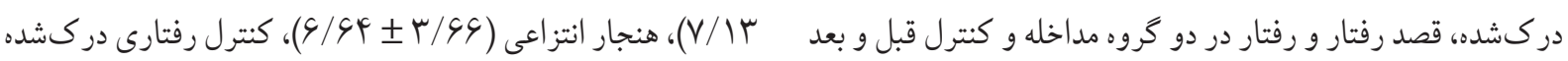
از آموزش، آزمون تى زوجى انجام شد و نشان داد كه در كروه مداخله، (

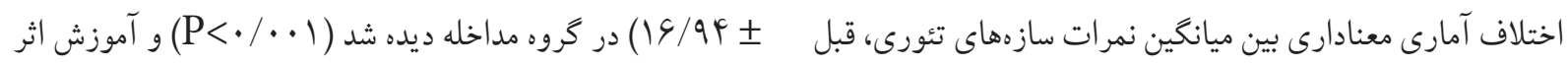

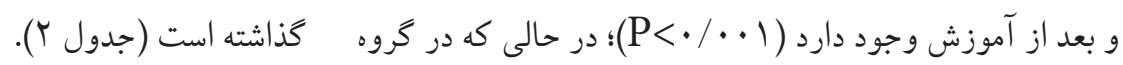

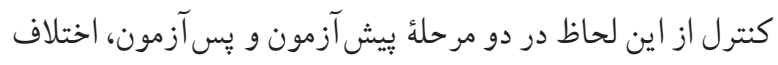

جدول ا. توزيع فراوانى مطلق و نسبى نمونهُ يزوهش برحسب ويخَى هاى جمعيتشناسى در دو گَروه مداخله و كنترل قبل از مداخله آموزشى

\begin{tabular}{|c|c|c|c|c|c|c|}
\hline \multirow{2}{*}{ سطح معنى دار } & \multicolumn{2}{|c|}{ كروه كنترل } & \multicolumn{2}{|c|}{ كروه مداخله } & \multirow{2}{*}{ كر } & \multirow{2}{*}{ كروه متغير } \\
\hline & درصد & تعداد & درصد & تعداد & & \\
\hline \multirow{5}{*}{$\cdot / r f q$} & $1 / 9$ & 1 & $r / \Lambda$ & $r$ & زير ·r سال & \multirow{5}{*}{ سن } \\
\hline & $\Delta / V$ & $r$ & $9 / f^{f}$ & $\Delta$ & . & \\
\hline & IV & 9 & $10 / 1$ & $\wedge$ & 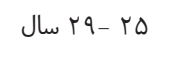 & \\
\hline & $r \Delta / r$ & $r q$ & $r \Delta / r$ & rF & . & \\
\hline & $r \cdot / r$ & 19 & $r s / f$ & if & بالاى r س سال & \\
\hline \multirow{2}{*}{.1111} & $\Delta r / \Lambda$ & rᄉ & 99 & ro & طبيعى & \multirow{2}{*}{ نوع زايمان } \\
\hline & $q V / r$ & ro & rq & 11 & سزارين & \\
\hline \multirow{4}{*}{$\cdot / F F \wedge$} & $11 / \pi$ & 4 & $9 / 4$ & $\Delta$ & ابتدايى & \multirow{4}{*}{ تحصيلات } \\
\hline & $9 /{ }^{f}$ & $\Delta$ & $\mid r / r$ & v & راهنمايى & \\
\hline & $r V / V$ & $r$. & $r s / f$ & if & دييلم & \\
\hline & $F 1 / \Delta$ & $r r$ & $0 \cdot / 9$ & $r r$ & دانشكاهى & \\
\hline \multirow{4}{*}{.$/ 4 I r$} & $r / \Lambda$ & r & $\Delta / V$ & r & ابتدايى & \multirow{4}{*}{ تحصيلات } \\
\hline & $10 / 1$ & $\wedge$ & iv & 9 & راهنمايى & \\
\hline & $r V / V$ & $r$. & $\mu f$ & 11 & دييلم & \\
\hline & $\varphi^{\mu} / q$ & $r \mu$ & $\mu r / q$ & $r \mu$ & دانشكاهى & \\
\hline \multirow[b]{2}{*}{.$/ 194$} & $r r / s$ & ir & $r r / l$ & IV & دولتى & \multirow[b]{2}{*}{ شغل يدر } \\
\hline & $V Y / q$ & il & $9 V / q$ & rs & آزاد & \\
\hline \multirow{2}{*}{.$/ 4 Y \wedge$} & $9 / 4$ & $\Delta$ & $10 / 1$ & $\wedge$ & شاغل & \multirow{2}{*}{ شغل مادر } \\
\hline & $9 \cdot / 9$ & rA & $\Lambda F / q$ & ro & خانهدار & \\
\hline
\end{tabular}


جدول r. مقايسة ميانگين و انحراف معيار نمرهٔ سازههاى تئورى رفتار برنامهريزىشده در دو گَروه مداخله و كنترل قبل و بعد از مداخلة آموزشى رفتار برنام

\begin{tabular}{|c|c|c|c|c|c|}
\hline نتايج آزمون Tزوجى & $\begin{array}{c}\text { اثر آموزش } \\
\text { MESD }\end{array}$ & 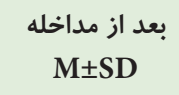 & قبل از مداخله & 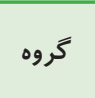 & 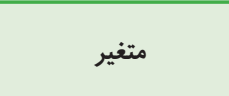 \\
\hline $\mathrm{P}<\cdot / \cdot \cdot 1$ & $r / \wedge F \pm r / r r$ & $. / 99 \pm 9 / \mathrm{Vr}$ & $r / I r \pm s / \Lambda \Lambda$ & 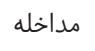 & \\
\hline \multirow[t]{2}{*}{$\mathrm{P}=\cdot / \cdot \wedge 1$} & $\cdot / \mu \Delta \pm 1 / \uparrow q$ & 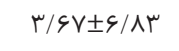 & 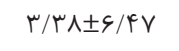 & 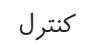 & آكاهى \\
\hline & $\mathrm{P}<\cdot / \cdot \cdot 1$ & \multicolumn{3}{|c|}{ آزمون مقايسة دو اثر (Tستقل) } & \\
\hline $\mathrm{P}<\cdot / \cdots 1$ & $V / I r \pm r / r \wedge$ & $r \pm r \wedge / 9 r$ & $r / \wedge \vee \pm r \mid / \wedge l$ & مداخله & \\
\hline \multirow[t]{2}{*}{$\mathrm{P}=\cdot / r T \Delta$} & $\cdot / r \cdot \pm 1 / r \mu$ & $\Delta / \Delta \Lambda \pm r \mid / \varsigma \varphi$ & $r / \wedge F \pm r \mid / \wedge \varepsilon$ & كنترل & نكرش \\
\hline & $\mathrm{P}<\cdot / \cdot \cdot 1$ & \multicolumn{3}{|c|}{ آزمون مقايسة دو اثر (TTستقل) } & \\
\hline $\mathrm{P}<\cdot / \cdots 1$ & $s / s q \pm \mu / s q$ & $r / \Delta F \pm r V / a r$ & $r / r r \pm r / / r$ & مداخله & \\
\hline \multirow[t]{2}{*}{$\mathrm{P}=. / 919$} & $. / 1 r \pm 1 / 94$ & $\Delta / r \wedge \pm r \mid / \uparrow \Delta$ & $r / \mu r \pm r \mid / \Delta \Lambda$ & 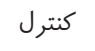 & هنجارهاى انتزاعى \\
\hline & $\mathrm{P}<\cdot / \cdots 1$ & \multicolumn{3}{|c|}{ آزمون مقايسٔ دو اثر (Tمستقل) } & \\
\hline $\mathrm{P}<\cdot / \cdot \cdot 1$ & $11 / \cdot \Delta \pm F / \mu r$ & $\Delta / V I \pm r V / I S$ & $V / V r \pm r s / I I$ & مداخله & \\
\hline \multirow[t]{2}{*}{$\mathrm{P}=\cdot|| \uparrow \mid$} & $\cdot / r Y \pm 1 / 1$ & $V / V V \pm r s / s r$ & $V / \Delta F \pm r s / \Lambda F$ & 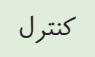 & كنترل رفتار دركشده \\
\hline & $\mathrm{P}<\cdot / \cdots 1$ & \multicolumn{3}{|c|}{ آزمون مقايسة دو اثر (Tستقل) } & \\
\hline $\mathrm{P}<\cdot / \cdot \cdot 1$ & $9 / V \pm r / 9 r$ & $r / \cdot r \pm r s / 10$ & $r / V F \pm r s / r \Delta$ & 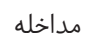 & \\
\hline \multirow[t]{2}{*}{$\mathrm{P}=. / .9 \Lambda$} & $\cdot / T F \pm \cdot / 9 \Delta$ & $r / 9 q \pm r s / v q$ & $r / q \cdot \pm r V / \cdot r$ & 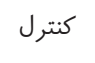 & قصد رفتار \\
\hline & $\mathrm{P}<\cdot / \cdot \cdot 1$ & \multicolumn{3}{|c|}{ آزمون مقايسٔ دو اثر (Tمستقل) } & \\
\hline $\mathrm{P}<\cdot / \cdot \cdot 1$ & $19 / 9 F \pm N / 1$ & $\Delta / \lambda r \pm r q / q$. & N/10 $\pm 1 r / 99$ & 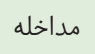 & \\
\hline \multirow[t]{2}{*}{$P=\cdot / 1 \cdot 9$} & $1 / r G \pm \Delta / G \varphi$ & $q / V F \pm \mid f / q q$ & $N / \Delta \cdot \pm \mid r / F r$ & كنترل - & رفتار \\
\hline & $\mathrm{P}<\cdot / \cdots 1$ & \multicolumn{3}{|c|}{ آزمون مقايسة دو اثر (TTمستقل) } & \\
\hline
\end{tabular}

اين يُوهش با هدف تعيين تأثير آموزش مبتنى بر تئورى رفتار كه تشكيل كلاسهاى آموزشى در مراكز جامع سلامت براى مادران تا

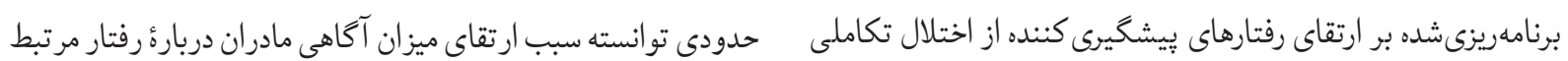

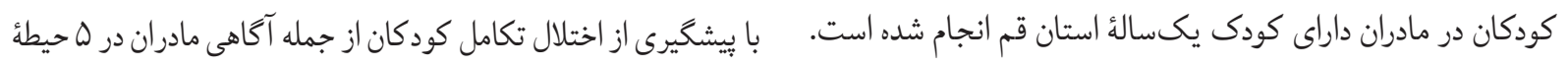

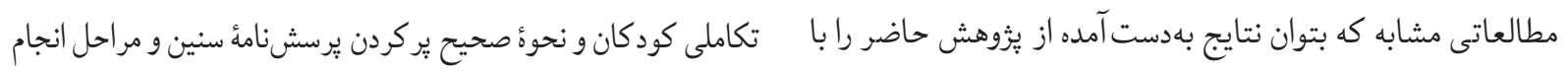

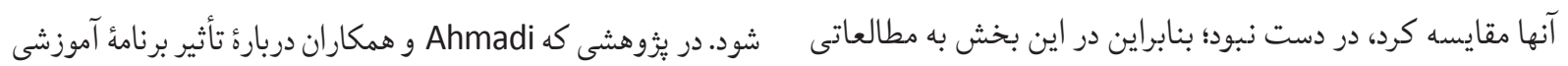

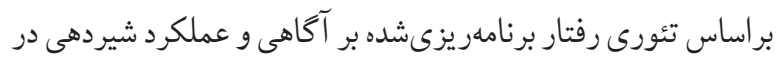
كه بهنوعى براساس تئورى انجام شده است، اشاره مىشود.

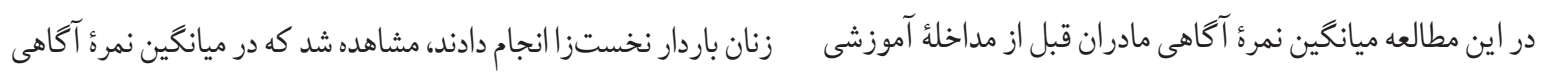

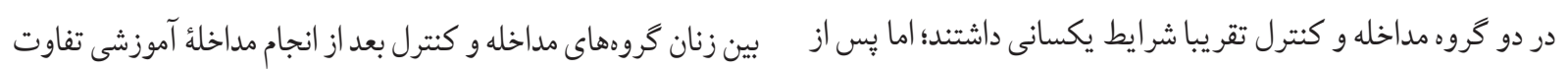

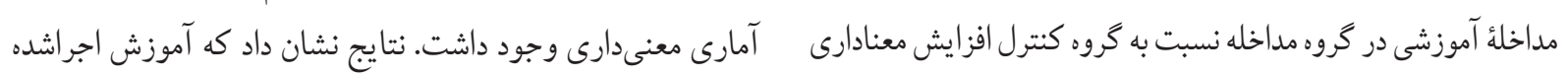

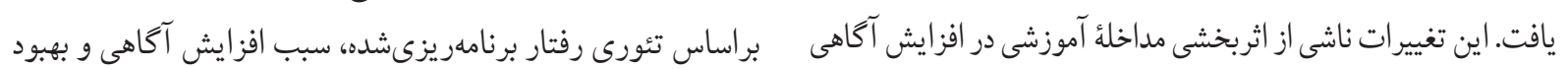

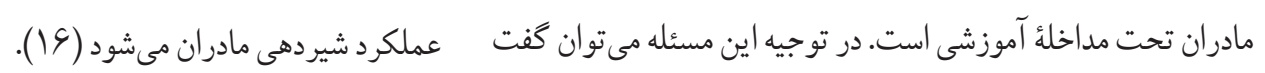


باردار در زمينهُ ترغيب به شيردهى از بِتان مؤثر بوده است (1) ). در خصوص ميزان كنترل رفتارى دركشدهُ مادران، ميانخين

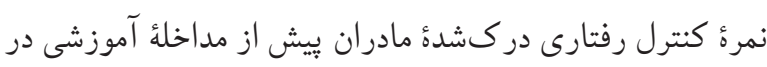
دو گروه مداخله و كنترل اختلاف معنادارى نداشتند؛ اما بعد از

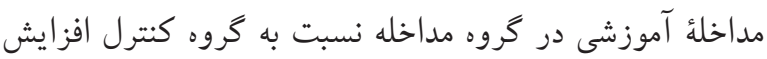

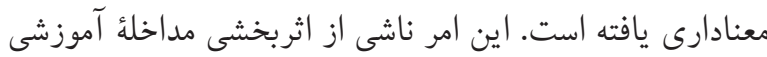

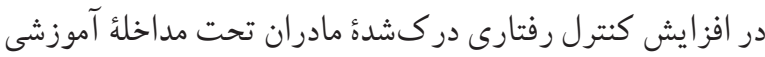

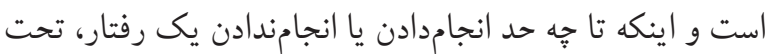

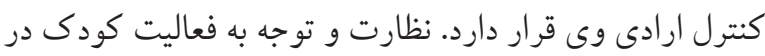

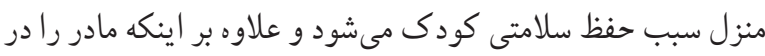

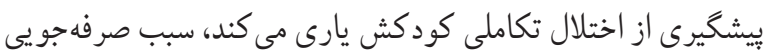
در هز ينهای درمانى خانو اده مى شود و اطمينان مادر به تو انايى خود

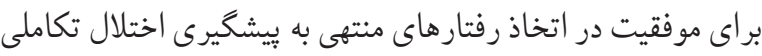
كودكش است تا احساس كند عواملى وجود دارند كه تسهيل كننده

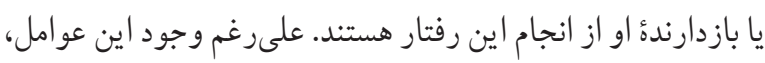

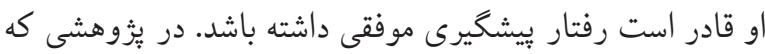

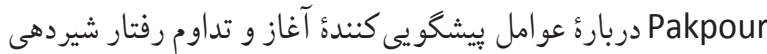

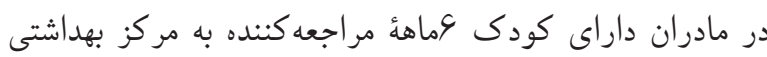

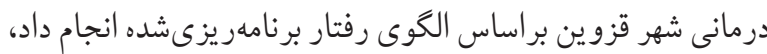
به اين نتيجه رسيد كه بايد مداخلات لازم در راستاى ارتقاى كنترل

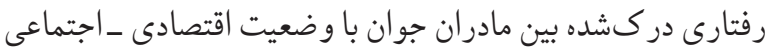
پاييين بهمنظور بهبود شيردهى انحصارى در نظر كرفته شود (19).

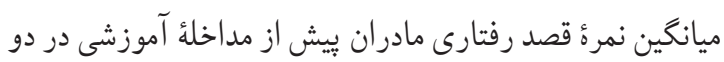
كروه مداخله و كنترل اختلاف معنادارى نداشتند؛ اما بعد از مداخلهُ آموزشى در كروه مداخله نسبت به كروه كنترل افزايش معنادادارى

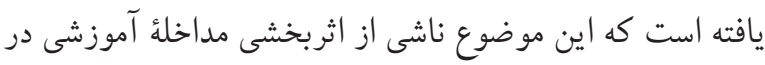

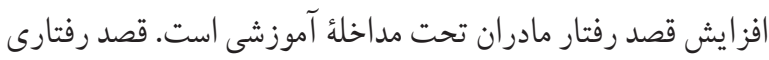

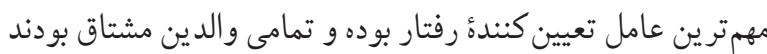

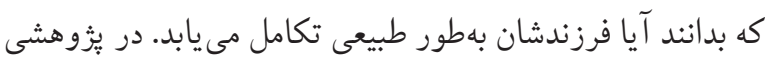
كه Rahimi دربارٔ بررسى كاربرد تئورى رفتار برنامهريزى شدهد

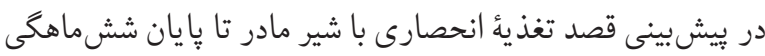

اما بايد توجه داشت كه افزايش آكاهى بهتنهايى نمىتواند

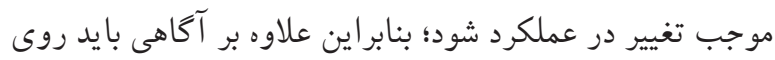

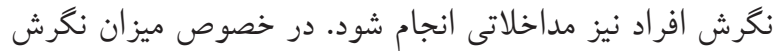

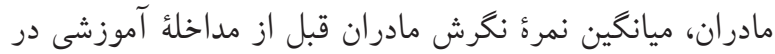

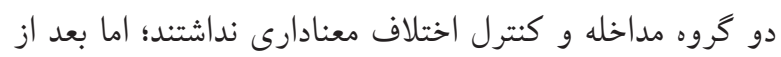

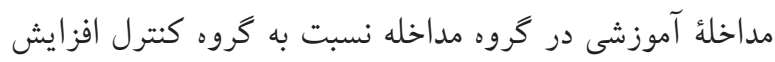

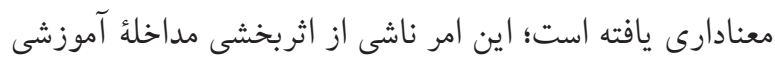

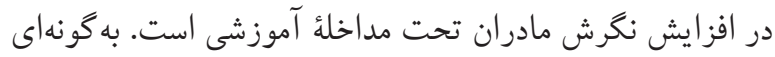

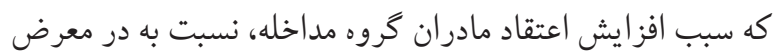

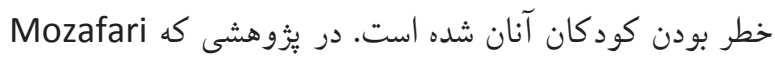
و همكاران دربارهُ سنجش سازههاى تئورى رفتار برنامهريزى شده در ييشخيرى از مصرف خودسرانه داروها در كودكان از سوى سئ مادران انجام دادند، بين متغير نكرش با عملكرد همبستكى مستقيم

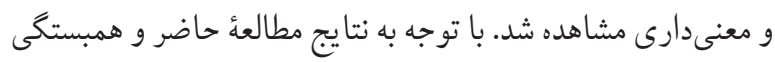

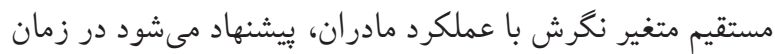
طراحى مداخلات عواقب منفى ناشى از مصرف خودسر انه داروها در كود كان در نظر گرفته شوند (IV) در خصوص ميزان هنجار انتزاعى مادران ميانخين نمرءٔهنجار

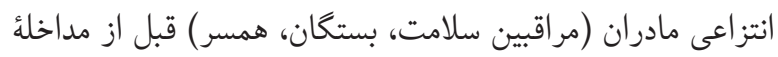
آموزشى در دو گروه مداخله و كنترل اختلاف معنادارى نداشتند؛ اما

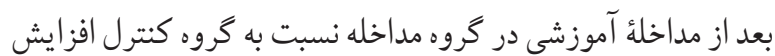

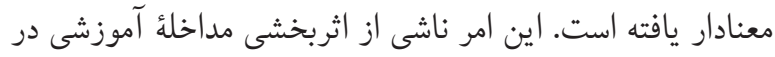

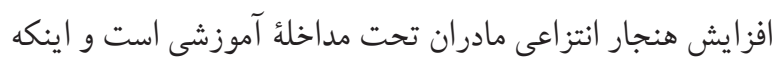

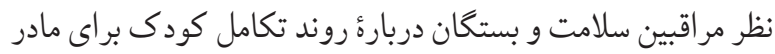

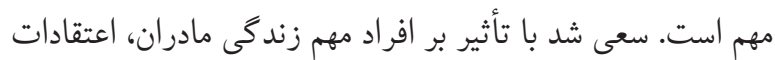

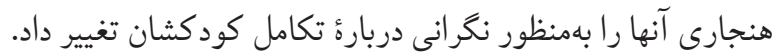

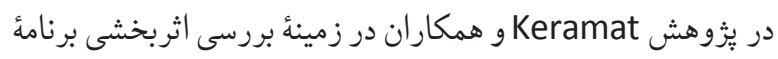

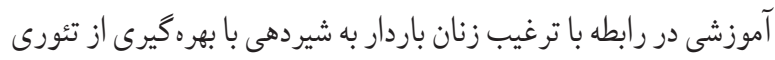

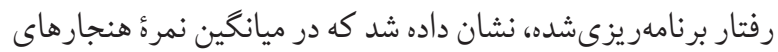
ذهنى بين زنان باردار گروههاى مداخله و كنترل بعد از انجام مداخلئ آموزشى تفاوت آمارى معنىدارى وجود داشت كه آموزش مادران 
تكميل ير سشنامها كه با توضيح دربارة طرح و ييغيرىهاى مكرر

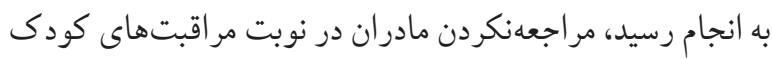

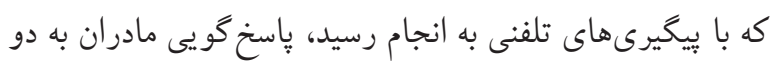

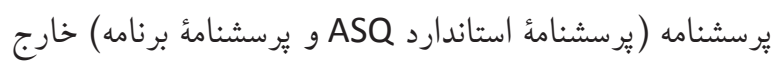

از حوصلة مادران بود.

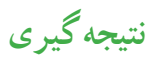

بهوروكلى نتايج يُوهش نشان داد كه آموزش براساس تئورى رفتار

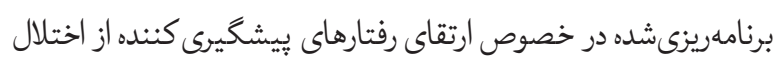

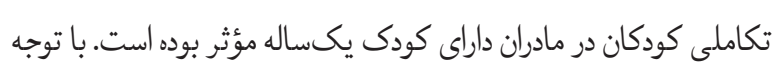

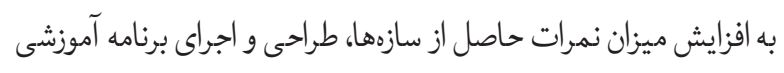

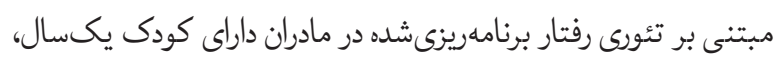

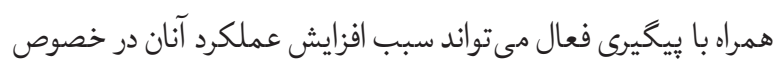
ييشكيرى از اختلال تكاملى كودكان شود. همجنين از از آنجا كه بهدنبال

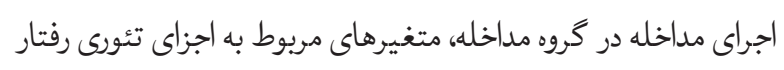

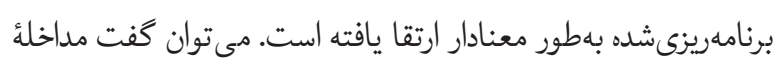

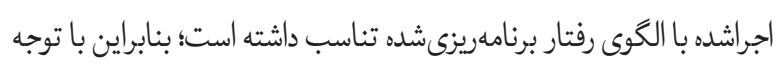

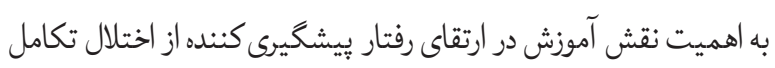
كودكان و عوارض ناشى از آن (از جمله مرك، معلوليت دائمى و موقت)

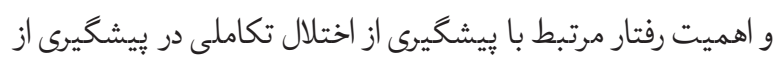

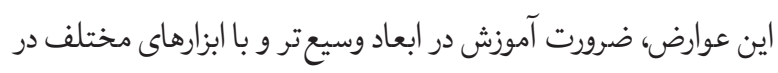

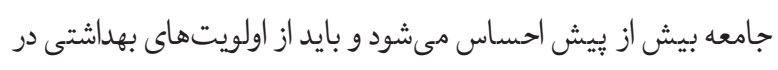

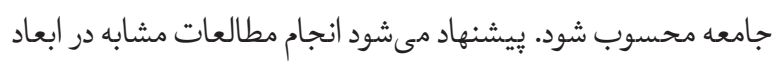

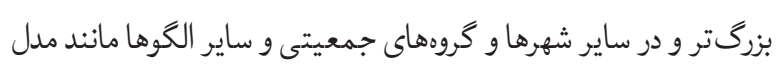
اعتقاد بهداشتى نيز صورت بذيرد.

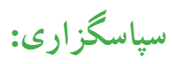

اين مقاله حاصل طرح تحقيقاتى ياياننامه براى دريافت درجة كارشناسى

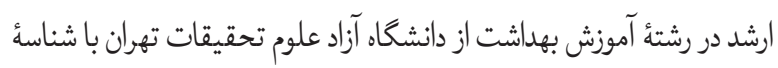
اخلاق IR.IAU.TMU.REC.1397.086 است. بدينوسيله از استادان

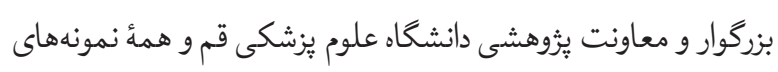

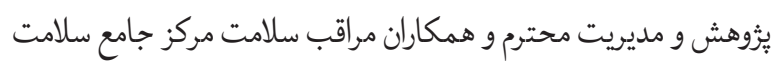
شهرستان قم بهخاطر همكارى هاى بىدريغ تشكر و قدردانى مى شودو.
در زنان باردار شهر قم انجام داد، يافتههاى مطالعه نشان داد كه

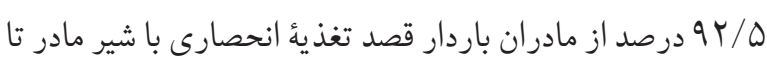

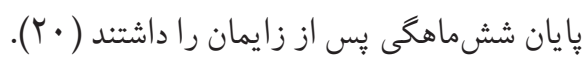

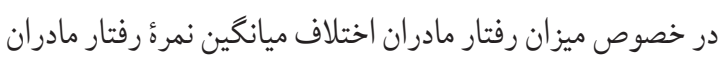

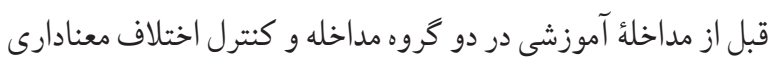

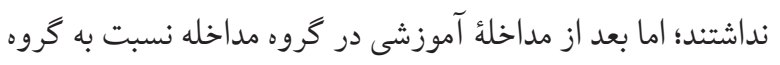

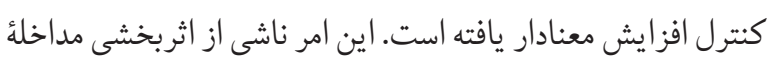

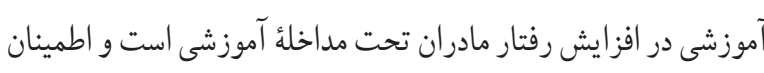

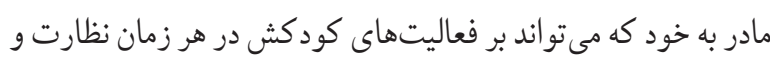

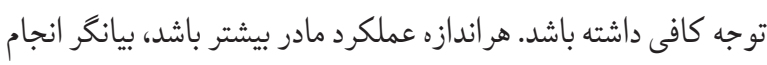
رفتارهاى بيشكيرى كنندة بهترى از طرف مادر است و اينكه مادران

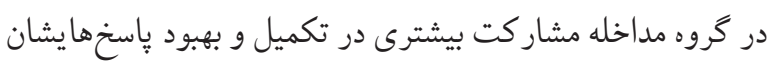

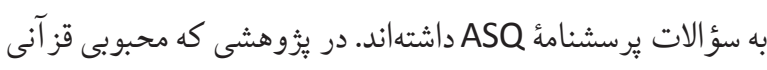

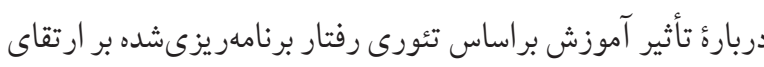

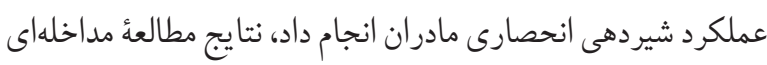

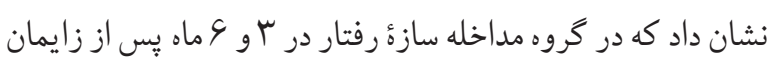

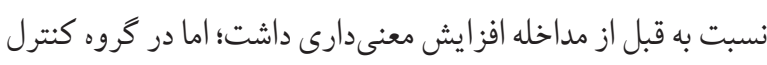
تفاوت معنى دارى مشاهده نشد. براساس نتايج اين مطالعه، مداخلة

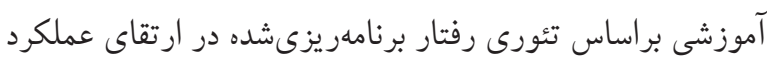

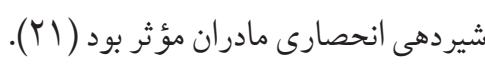

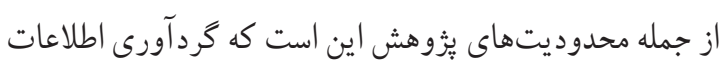

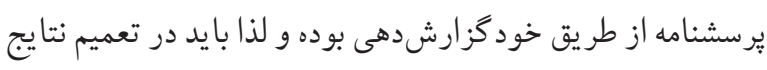

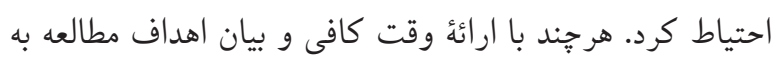

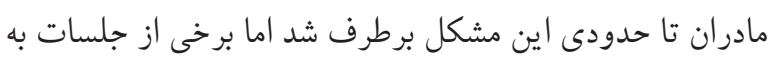

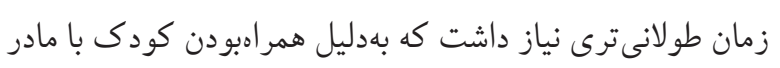

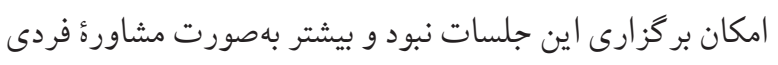

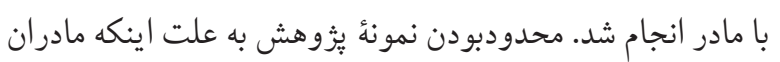
حتما بايد داراى كودى يكساله باشند، باعث شده بود تا با زمان اندان

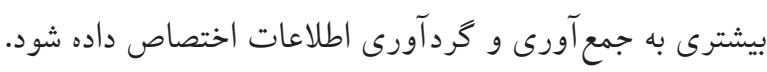

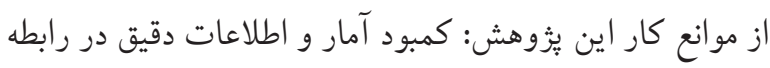

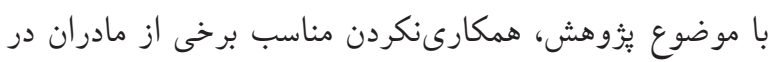




$$
\text { تضاد منافعى وجود ندارد. }
$$

\section{References}

1. Shams B, Najimi A, Golshiri P. The evaluation of mothers) participation project in children's growth and development process based on the CIPP model. Community Health J. 2010;6(2):165-171

2. Malekshahi F. Review the Training Needs of Mothers of Children under One Year Referred to Hhealth Centers on Complementary Feeding and Providing Appropriate Solutions in khorram Abad 2006. Ninth Congress of Nutrition; Tabriz: Tabriz University of Medical Sciences; 2007.

3. Alatartseva E, Barysheva G, editors. What Is Well-Being in the Modern Society: Objective View. SHS Web of Conferences; 2016: EDP Sciences.

4. Demirci A, Kartal M. The Prevalence of Developmental Delay among Children Aged 3-60 Months in Izmir, Turkey. Child Care, Health and Development. 2016;42(2):213-9.

5. Zareipour M, SadaghianifarA, Ghelichi Ghojogh M, Ebrahimi $\mathrm{H}$, Asgharzadeh P, Valizadeh R. The Relationship between Developmental Growth of Children and Anthropometric Indices in Urmia City, North West of Iran. Int J Pediatr.2017;5(41): 4975-4984.

6. Kvestad I, Taneja S, Kumar T, Bhandari N, Strand TA, Hysing $M$. The Assessment of Ddevelopmental Sstatus Using the Ages and Stages Questionnaire-3 in Nnutritional Rresearch in North Indian Young Children. Nutrition Journal. 2013;12(1):50.

7. Sajedi F, Vameghi R, Kraskian Mojemba A, Habibollahi L, Lornejad $H$, Delavar B. Standardization and validation of the ASQ developmental disorders screening tool in children of Tehran city. Tehran University Medical Journal. 2012;70(7):436-446 (Persian)

8. Kavousipor S, Golipour F, Hekmatnia M. Relationship between a Child's Cognitive Skills Andthe Inclusion of Age Appropriate Toys in the Home Environment. Journal of Rehabilitation Sciences and Research. 2016;3(4): 103-108.

9. Hsiao C, Richter L, Makusha T, Matafwali B, Heerden A, Mabaso M. Use of the Ages and Stages Questionnaire Aadapted for South Africa and Zambia. Child: Care, Health and Development. 2017;43(1):59-66.

10. Steenisa L, Verhoevena M, Hessenb D, van Baara A. Parental and professional assessment of early child development: The ASQ-3 and the Bayley-III-NL. Early Human Development 2015;91(3): 217-225

11. Rothstein A, Miskovic A, Nitsch K. Brief Review of Psychometric Properties and Clinical Utility of the Ages and Stages Questionnaires, for Evaluating Pediatric Development. Archives of Physical Medicine and Rehabilitation. 2017;98(4):809-10.
سهم تمامى نويسندگان در اين مطالعه يكسان است و هيجگگنه

12. Demirci A, Kartal M. The Prevalence of Developmental Delay among Children Aged 3-60 Months in Izmir, Turkey. Child Care, Health and Development. 2016;42(2):213-9.

13. Siuki HA, Peyman N, Vahedian-Shahroodi M, GholianAval M, Tehrani H. Health Education Intervention on HIV/ AIDS Prevention Behaviors among Health Volunteers in Healthcare Centers: An Applying the Theory of Planned Behavior. Journal of Social Service Research. 2019;45(4):582-8.

14. Khorrami Z, Namdar A. Development Status among OneYear-Old Children Referring to Urban Health Centers of Jahrom: An Assessment based on Ages and Stages Questionnaires. Community Health. 2018;5(2):141-150

15. Khorrami Z, Namdar A. Development Status among OneYear-Old Children Referring to Urban Health Centers of Jahrom: An Assessment based on Ages and Stages Questionnaires. Community Health. 2018; 5(2):141-50

16. Ahmadi M, Jahanara S, Moeini B, Nasiri M. Impact of Educational Program Based on the Theory of Planned Behavior on Primiparous Pregnant Women's Knowledge and Behaviors Regarding Breast Feeding. J of health \& care. 2014;16(1):19-31

17. Mozafari S, Shamsi M, Roozbehani N, Ranjbaran M. Designing an Assessment Tool for Preventative SelfMedication Behaviors in Children under 6 years of age based on the Theory of Planned Behavior. Community Health journal. 2015; 9(2): 1-9.

18. Keramat A, Masoumi S, Shobeiri F, Raei M, Andarzgoo $M$, Babazadeh R. Effectiveness of educational program related to persuade women for breast feeding based on theory of planned behavior (TPB). Sci J Hamadan Nurs Midwifery Fac. 2013; 21(2): 21-31

19. Pakpour A, Alijanzadeh M, Pouresmaeil M, Taherkhani F, Mohammadgholiha R, Jozi N. Predictive Factors Associated with Breastfeeding lintiation and Duration Behaviors of 6-months Postpartum Mothers Referred to Health Centers in the City of Qazvin Based on Theory of Planned Behavior.j Health Educ Health Promot. 2016;4(1):20-30.

20. Rahimi T, Dehdari T, Faryabi R, Ghazvinian L. The Applicability of the Theory of Planned- Behavior in Predicting the Intention to Exclusive Breastfeeding among Pregnant Women in Qom in 2014. JRUMS. 2015; 14 (4):299-310 http://journal.rums.ac.ir/article-1-2433-en. html

21. Mahbobi Gazaani F. The effect of health education based on theory of planed behaviour on behavioral promotion of exclusive breast feeding of mothers. Arak University of Medical Sciences J.2014. 